\title{
ANNUAL BIBLIOGRAPHY*
}

\section{Art and Archaeology}

Books and Articles

Bertrand, Arnaud. "Conquête et Occupation de La Frontière NordOuest Au Temps Des Han Occidentaux (206 Av. J.-C.—9 Apr. J.-C.)." In La Guerre et Les Eléments, edited by Jean Baechler and Jérôme de Lespinois, 211-46. Paris: Hermann, 2019.

Brunson, Katherine, Ren Lele, Zhao Xin, Dong Xiaoling, Wang Hui, Zhou Jing, and Rowan Flad. "Zooarchaeology, Ancient MtDNA, and Radiocarbon Dating Provide New Evidence for the Emergence of Domestic Cattle and Caprines in the Tao River Valley of Gansu Province, Northwest China." Journal of Archaeological Science: Reports 31 (2020), https://doi.org/10.1016/j.jasrep.2020.102262.

Cao, Dingyun. "Late Shang: Fu Zi [Fu Hao] and M5 at Xiaotun." In The Oxford Handbook of Early China, edited by Elizabeth Childs-Johnson, 350-61. New York: Oxford University Press, 2020.

Caspari, Gino. "Quantifying Ritual Funerary Activity of the Late Prehistoric Southern Kanas Region (Xinjiang, China)." Asian Perspectives 59.2 (2020), 421-52.

Chan, Annie. "Modules of Stone Construction and the Building of Ritual and Social Traditions in Prehistoric Xinjiang (China) and Mongolia." Asian Perspectives 59.2 (2020), 330-37.

Chan, Annie, and Dexin Cong. "Results of Field Research on Ancient Stonework in the River Valleys of Bortala and Ili in Western Tian Shan (Xinjiang, China)." Asian Perspectives 59.2 (2020), 385-420.

Chi, Zhang, and Marcella Festa. "Archaeological Research in the Ili Region: A Review." Asian Perspectives 59.2 (2020), 338-84.

Childs-Johnson, Elizabeth. "Jade Age Adornment of the Liangzhu Elite." In The Art and Archaeology of Bodily Adornment: Studies from Central and East Asian Mortuary Contexts, edited by Sheri Lullo and Leslie Wallace, 141-6o. London: Routledge, 2021.

—. "The Jade Age Revisited, ca. 3500-2000 BCE." In The Oxford Handbook of Early China, edited by Elizabeth Childs-Johnson, 101-17. New York: Oxford University Press, 2020.

—_. "Late Shang Ritual and Residential Architecture at Great City Shang, Yinxu in Anyang, Henan." In The Oxford Handbook of Early

*Compiled by Wen-Yi Huang 黃文儀, Postdoctoral Fellow, Institute of Chinese Literature and Philosophy, Academia Sinica; email: wenyi.huang@mail.mcgill.ca.

(C) The Society for the Study of Early China and Cambridge University Press 2021 
China, edited by Elizabeth Childs-Johnson, 314-49. New York: Oxford University Press, 2020.

—. "Shang Belief and Art." In The Oxford Handbook of Early China, edited by Elizabeth Childs-Johnson, 285-303. New York: Oxford University Press, 2020.

—. "Who Is That Human at Shimao? China's Ancient Belief in Metamorphic Power." Orientations 51.4 (2020), 2-13.

Childs-Johnson, Elizabeth, and John S Major. "Chu Religion and Art." In The Oxford Handbook of Early China, edited by Elizabeth ChildsJohnson, 711-44. New York: Oxford University Press, 2020.

Cook, Scott. "Bells and Music in the Zhou." In The Oxford Handbook of Early China, edited by Elizabeth Childs-Johnson, 471-92. New York: Oxford University Press, 2020.

—. "Technology in a New Key: Toward a Reexamination of Musical Theory and Practice in the Zeng Hou Yi 曾侯乙 Bells." T'oung Pao 106.3-4 (2020), 219-65.

Cui, Zuowen, Quanjia Chen, Youqian Li, Wanbo Li, Shituo Liu, and Tianxu Wei. "Paleolithic Lithic Artifacts and Industries from Survey along the Muling River Basin, Heilongjiang, China." Asian Archaeology 3.1 (2020), 35-46.

Deng, Hui, and Jun Li. "Identification of Domestic Chicken Bones in Archaeological Sites." Chinese Archaeology 20.1 (2020), 193-200.

Fang, Xiangming. "The Neolithic Revolution in the South, ca. 7/60oo2000 BCE, Majiabang, Hemudu, Daxi, and Songze Cultures." In The Oxford Handbook of Early China, edited by Elizabeth Childs-Johnson, 53-72. New York: Oxford University Press, 2020.

$\mathrm{Fu}$, Yongxu. "On Cupstones in South China." Chinese Archaeology 20.1 (2020), 123-31.

Fullagar, Richard, Elspeth Hayes, Xingcan Chen, Xiaolin Ma, and Li Liu. "A Functional Study of Denticulate Sickles and Knives, Ground Stone Tools from the Early Neolithic Peiligang Culture, China." Archaeological Research in Asia 26 (2021), 100265, https://doi.org/10.1016/j. ara.2021.100265.

Guangdong Provincial Institute of Cultural Relics and Archaeology, School of Archaeology and Museology, Peking University, and Yingde Museum. "The Qingtang Site in Yingde City, Guangdong Province." Chinese Archaeology 20.1 (2020), 1-12.

$\mathrm{He}, \mathrm{Nu}$. "Longshan Culture Issues: Taosi and Cosmology." In The Oxford Handbook of Early China, edited by Elizabeth Childs-Johnson, 139-57. New York: Oxford University Press, 2020.

$\mathrm{He}$, Yuling, and Chunmei Ma. "The Function of the Bronze Rulers From the Tomb of Fu Hao, With a Discussion of the Usage of Shang and Zhou Dynasty Bronze Jue-Cups and Gu-Goblets." Chinese Cultural Relics 5.1-4 (2018), 234-47. 
Heilongjiang Provincial Institute of Cultural Relics and Archaeology, and Commission for Preservation of Ancient Monuments, Raohe County. "The Excavation of Zone III of the Xiaonanshan Site in Raohe County, Heilongjiang Province in 2015." Chinese Archaeology 20.1 (2020), 87-96.

Hein, Anke, and Wa Ye. "Soil, Hands, and Heads: An Ethnoarchaeological Study on Local Preconditions of Pottery Production in the Wei River Valley (Northern China)." Advances in Archaeomaterials 1.1 (2020), 51-104.

Higham, Charles F.W. "The Later Prehistory of Southeast Asia and Southern China: The Impact of Exchange, Farming and Metallurgy." Asian Archaeology 4.2 (2021), 63-93.

History Museum of Quxian County, and Sichuan Provincial Institute of Cultural Relics and Archaeology. "The Chengba Site in Quxian County, Sichuan Province." Chinese Archaeology 20.1 (2020), 54-68.

Huang, Juan. "The Unearthed Bronze Coin Molds and the Evolution of Coin Technology in the Warring States Period and Qin-Han Dynasties." Chinese Archaeology 20.1 (2020), 158-66.

Hubei Provincial Institute of Cultural Relics and Archaeology, Xiangyang Municipal Institute of Cultural Relics and Archaeology, and Xin Chen. "The Color Paintings on Lacquered Wooden Crossbows Unearthed From the Chu Tombs at the Jiuliandun Site in Zaoyang City, Hubei Province." Chinese Cultural Relics 5.1-4 (2018), 120-37.

Institute of Archaeology, Chinese Academy of Social Sciences, Hubei Provincial Institute of Cultural Relics and Archaeology, Jingzhou Municipal Museum, and Commission for Preservation of Ancient Monuments, Shayang County. "The Wangiiabang Cemetery of the Chenghe Site of the Neolithic Age in Shayang County, Hubei Province." Chinese Archaeology 20.1 (2020), 13-24.

Jaffe, Yitzchak Y. "Recent Research on the Western Zhou Period: Introduction to the 2019 Essays." Archaeological Research in Asia 23 (2020), 100160, https://doi.org/10.1016/j.ara.2019.10016o.

—_. "A Grave Matter: Linking Pastoral Economies and Identities in the Upper Xiajiadian Culture (1200-60o BCE), China." World Archaeology 52.1 (2020), 133-46.

Jaffe, Yitzchak Y., and Anke Hein. "Considering Change with Archaeological Data: Reevaluating Local Variation in the Role of the $\sim 4.2 \mathrm{kBP}$ Event in Northwest China." The Holocene 31.2 (2020), 169-82.

Jin, Guiyun, Songtao Chen, Hui Li, Xianjun Fan, Aiguo Yang, and Steven Mithen. "The Beixin Culture: Archaeobotanical Evidence for a Population Dispersal of Neolithic Hunter-Gatherer-Cultivators in Northern China." Antiquity 94. 378 (2020), 1426-43.

Joint Archaeological Team of Shanxi Provincial Institute of Archaeology, Yuncheng Cultural Relics Task Force, and Jiangxian County Cultural 
Relics Agency, Research Center for the Archaeology of North China, Shanxi University, and Collaborative Innovation Center of Studies of Unearthed Documents and Ancient Chinese Civilization at Renmin University. "The Excavation of Tomb M2158 at the Hengshui Cemetery of the Western Zhou Dynasty in Jiangxian County, Shanxi Province." Chinese Archaeology 20.1 (2020), 97-110.

Khayutina, Maria. "Western Zhou Cultural and Historic Setting." In The Oxford Handbook of Early China, edited by Elizabeth Childs-Johnson, 365-400. New York: Oxford University Press, 2020.

Kost, Catrin. "A Matter of Representation-Personal Hygiene in Eastern Zhou-Dynasty China (771-256 BCE)." In Cleaning and Value: Interdisciplinary Investigations, edited by Isabel Bredenbröker, Christina Hanzen, and Felix Kotzur, 129-54. Leiden: Sidestone Press, 2020.

Lai, Celine Yuen Yan. Contacts Between the Shang and the South c. 13001045 BC: Resemblance and Resistance. Oxford: British Archaeological Reports Oxford, 2019.

Lam, Wengcheong. "Iron Technology and Its Regional Development during the Eastern Zhou Period." In The Oxford Handbook of Early China, edited by Elizabeth Childs-Johnson, 595-614. New York: Oxford University Press, 2020.

Li, Baihua. "A Preliminary Study on Ancient Chinese Large Rectangular Bronze Plates." Orientations 52.1 (2021).

$\mathrm{Li}$, Haichao, and Rebecca O'Sullivan. "Diachronic Change in the Shang Dynasty Ritual Package." Archaeological Research in Asia 23 (2020), 100210, https://doi.org/10.1016/j.ara.2020.100210.

Li, Kin Sum (Sammy). "What the Elites Actually Wore in 500-300 B.C.E. China: Evidence from Textiles, Bamboo, and Bronzes." Early China 43 (2020), 161-205.

Li, Xiuzhen. Bronze Weapons of the Qin Terracotta Warriors: Standardisation, Craft Specialisation and Labour Organisation. Oxford: British Archaeological Reports, 2020.

Li, Yingfu. "The 'Bowl-Shaped' Bloomeries of Pingnan County, Guangxi Zhuang Autonomous Region and the Origins of 'Bowl-Shaped' Bloomery in China." Chinese Archaeology 20.1 (2020), 167-70.

Li, Yue, Chengrui Zhang, William T. T. Taylor, Liang Chen, Rowan K. Flad, Nicole Boivin, Huan Liu, Yue You, Jianxin Wang, Meng Ren, Tongyuan Xi, Yifu Han, Rui Wen, and Jian Ma. "Early Evidence for Mounted Horseback Riding in Northwest China." Proceedings of the National Academy of Sciences of the United States of America 117.47 (2020), 29569-76.

Li, Yue, Chengrui Zhang, William T. T. Taylor, Liang Chen, Rowan K. Flad, Nicole Boivin, Huan Liu, Yue You, Jianxin Wang, Meng Ren, Tongyuan Xi, Yifu Han, Rui Wen, and Jian Ma. "Reply to Shelach- 
Lavi et al.: Implications of the Horse Assemblages from Shirenzigou and Xigou." Proceedings of the National Academy of Sciences of the United States of America 118.16 (2021), e2025947118, https:/ / doi.org/10.1073/ pnas.2025947118.

Liu, Bin. "Liangzhu Culture and the Ancient City of Liangzhu." In The Oxford Handbook of Early China, edited by Elizabeth Childs-Johnson, 118-38. New York: Oxford University Press, 2020.

Liu, Ruiliang, A. Mark Pollard, Qin Cao, Cheng Liu, Victoria Sainsbury, Philly Howarth, Peter Bray, Limin Huan, Bohao Yao, Yuting Fu, and Jigen Tang. "Social Hierarchy and the Choice of Metal Recycling at Anyang, the Last Capital of Bronze Age Shang China." Scientific Reports 10.1 (2020), 18794.

Liu, Xu. "An Archaeological Perspective of the Western Zhou Domain." Archaeological Research in Asia 23 (2020), 100159, https://doi. org/10.1016/j.ara.2019.100159.

Liu, Yiting, Yang Wang, Rowan Flad, and Xingshan Lei. "Animal Sacrifice in Burial: Materials from China during the Shang and Western Zhou Period." Archaeological Research in Asia 22 (2020), https://doi. org/10.1016/j.ara.2020.100179.

Lu, Chenggan, Feng Xie, and Peixin Wang. “The Selection and Rejection of Animal Face Pattern Tiles: The Bohai State Examined from a Greater East Asian Perspective." Asian Archaeology 4.1 (2020), 31-40.

Miller, Allison R. Kingly Splendor: Court Art and Materiality in Han China. New York: Columbia University Press, 2021.

Okada, Fumio. "A Scientific Investigation of Lacquer Ware Incised KaoGong: Excavated from Barrow No.7, Tsaram Xiongnu Cemetery." Asian Archaeology 3.1 (2020), 71-74.

Otani, Ikue. "A Reconsideration of a Chinese Inscription Carved on Lacquerware Unearthed from Barrow No. 7 of the Tsaram Xiongnu Cemetery (Buryatia, Russia): New Reflections on the Organization of the Central Workshops of the Han." Asian Archaeology 3.1 (2020), 59-70.

Peng, Peng. Metalworking in Bronze Age China: The Lost-Wax Process. Amherst: Cambria Press, 2020.

Pollard, A. M., and Ruiliang Liu. "Bronze Alloying Practice in Ancient China-Evidence from Pre-Qin Coin Analyses." Journal of Archaeological Science 126 (2021), 105322, https:/ / doi.org/10.1016/j.jas.2020.105322.

Psarras, Sophia-Karin. Sources of Han Décor: Foreign Influence on the Han Dynasty Chinese Iconography of Paradise (206 BC-AD 220). Oxford: Archaeopress, 2020.

Quinn, P., Y. Yang, Y. Xia, X. Li, S. Ma, S. Zhang, and D. Wilke. “Geochemical Evidence for the Manufacture, Logistics and Supply-Chain Management of Emperor Qin Shihuang's Terracotta Army, China." Archaeometry 63.1 (2020), 40-52. 
Sebillaud, Pauline, James Williams, Xiaoxi Liu, and Lixin Wang. "Changing Settlement Patterns and Subsistence Strategies in Northeast China: Results of the Yueliang Regional Survey." Archaeological Research in Asia 25 (2021), 100250, https://doi.org/10.1016/j.ara.2020.100250.

Shaanxi Academy of Archaeology, School of Cultural Heritage, Northwest University, and Yan'an Municipal Institute of Cultural Relics. "The Lushanmao Site of the Neolithic Age in Yan'an City, Shaanxi Province." Chinese Archaeology 20.1 (2021), 25-40.

Shaanxi Academy of Archaeology, Weinan Museum, and Chengcheng County Culture and Tourism Bureau. "The Liujiawa Site of the Rui State of the Eastern Zhou in Chengcheng County, Shaanxi Province." Chinese Archaeology 20.1 (2020), 41-53.

Shan, Siwei, Limin He, Shuai Yao, Jian Wang, Xiyun Yu, and Tao Li. "The Emergence of Walled Towns in Prehistoric Middle Yangtze River Valley: Excavations at the Zoumaling Site." Archaeological Research in Asia 26 (2021), 100285, https:/ / doi.org/10.1016/j.ara.2021.100285.

Shi, Jie. "The Artistic Revolution in the Warring States Period." In The Oxford Handbook of Early China, edited by Elizabeth Childs-Johnson, 745-78. New York: Oxford University Press, 2020.

Shi, Jingsong. "Shang Dynasty Bronzes and Society in Southern China: An Illustration of Complexity and Diversity." Chinese Archaeology 20.1 (2020), 151-57.

Smith, Jonathan. "The Cultural and Historical Setting of the Shang." In The Oxford Handbook of Early China, edited by Elizabeth Childs-Johnson, 227-52. New York: Oxford University Press, 2020.

Song, Guoding. "Early and Middle Shang Periods." In The Oxford Handbook of Early China, edited by Elizabeth Childs-Johnson, 253-84. New York: Oxford University Press, 2020.

Stevens, Chris J., Gideon Shelach-Lavi, Hai Zhang, Mingyu Teng, and Dorian Q. Fuller. "A Model for the Domestication of Panicum Miliaceum (Common, Proso or Broomcorn Millet) in China." Vegetation History and Archaeobotany 30.1 (2021), 21-33.

Sun, Yan. "Bronze Vessels: Style, Assemblages, and Innovations of the Western Zhou Period." In The Oxford Handbook of Early China, edited by Elizabeth Childs-Johnson, 451-70. New York: Oxford University Press, 2020.

Takahama, Shū. "Two Technical Traditions of Casting Horse Bits in China and Their Relationships with the Steppe Area." Asian Archaeology 3.1 (2020), 47-57.

Tang, Chung, Mana Hayashi Tang, Guoxiang Liu, and Yadi Wen. "The Neolithic Jade Revolution in Northeast China." In The Oxford Handbook of Early China, edited by Elizabeth Childs-Johnson, 73-10o. New York: Oxford University Press, 2020. 
Tang, Chung, and Fang Wang. "The Spread of Erlitou Yazhang to South China and the Origin and Dispersal of Early Political States." In The Oxford Handbook of Early China, edited by Elizabeth Childs-Johnson, 202-23. New York: Oxford University Press, 2020.

Tang, Yuyun. "On the Source 'Composition' of the Bronze Vessels in the Burials of the Yinxu Site." Chinese Archaeology 20.1 (2020), 139-50.

von Falkenhausen, Lothar. "An Archaeological Perspective on Chu Economy." In Chu wenhua yu Changjiang zhongyou diqu de zaoqi kaifa guoji xueshu yantaohui lunwenji 楚文化與長江中游地區的早期開發國 際學術研討會論文集, edited by Shaohua Xu, 116-38. Wuhan: Wuhan University Press, 2021.

Wallace, Leslie. "Does a Feather in Your Hat a Barbarian Make? Headgear and Hairstyles in Han Dynasty Tomb Murals in the Ordos." In The Art and Archaeology of Bodily Adornment: Studies from Central and East Asian Mortuary Contexts, edited by Sheri Lullo and Leslie Wallace, 161-75. London: Routledge, 2021.

Wang, Wenjing, and Weihong Wu. "Lingjiatan Early Complex Societies and Social Organization in the Yuxi Valley, China." Archaeological Research in Asia 25 (2021), 100259, https://doi.org/10.1016/j. ara.2021.100259.

Wei, Lia. "Funerary Expressions on Imperial Frontiers: Burial Caves South of the Yangzi River (2nd to 3rd Century CE)." Archaeological Research in Asia 26 (2021), 100263, https://doi.org/10.1016/j. ara.2021.100263.

Womack, Andrew, Rowan Flad, Jing Zhou, Katherine Brunson, Fabian H. Toro, Xin Su, Anke Hein, Jade d'Alpoim Guedes, Guiyun Jin, Xiaohong Wu, and Hui Wang. "The Majiayao to Qijia Transition: Exploring the Intersection of Technological and Social Continuity and Change." Asian Archaeology 4.2 (2021), 95-120.

$\mathrm{Xu}$, Hong. "The Bronze-Casting Revolution and the Ritual Vessel Set." In The Oxford Handbook of Early China, edited by Elizabeth Childs-Johnson, 190-201. New York: Oxford University Press, 2020.

—. "Introduction: Definitions, Themes, and Debate." In The Oxford Handbook of Early China, edited by Elizabeth Childs-Johnson, 161-75. New York: Oxford University Press, 2020.

$\mathrm{Xu}$, Hong, and Xiang Li. "Settlements, Buildings, and Society of the Erlitou Culture." In The Oxford Handbook of Early China, edited by Elizabeth Childs-Johnson, 176-89. New York: Oxford University Press, 2020.

Ye, Wa and Anke Hein. "A Buried Past: Five Thousand Years of (Pre) History on the Jing-Wei Floodplain." Asian Archaeology 4.1 (2020), 1-15.

Yi, Mingjie, Xing Gao, Fuyou Chen, Shuwen Pei, and Huimin Wang. "Combining Sedentism and Mobility in the Palaeolithic-Neolithic 
Transition of Northern China: The Site of Shuidonggou Locality 12." Antiquity 95.380 (2021), 292-309.

Zhang, Changping. "Shang Bronze-Casting Technology and Metallurgy Issues." In The Oxford Handbook of Early China, edited by Elizabeth Childs-Johnson, 304-13. New York: Oxford University Press, 2020.

Zhang, Chi, Jianing He, Xiaohong Wu, Yinqiu Cui, Hua Wang, Jiangkai Zhang, Li Fan, and Wenming Yan. "Study on the Burial Practice of Tomb M13 of the Yangshao Culture at Baligang Site in Dengzhou City." Chinese Archaeology 20.1 (2020), 132-38.

Zhang, Tian'en. "On the Dates and Chronological Sequence of the Marquises of Zeng at the Yejiashan Cemetery in Suizhou." Chinese Cultural Relics 5.1-4 (2018).

Zhu, Simei, Fajun Li, Xianglong Chen, Xianguo Fu, and Yaowu Hu. "Subsistence and Health in Middle Neolithic (9000-700o BP) Southern China: New Evidence from the Dingsishan Site." Antiquity 95.379 (2021), 13-26.

\section{Reviews}

Shi. Modeling Peace: Royal Tombs and Political Ideology in Early China. Prüch, Margareta M. Monumenta Serica 68.2 (2020), 567-72.

\section{Comparative Studies}

\section{Books and Articles}

Bai, Chunxiao. "The Cyclical Views of Human History in Thucydides' Archaeology and Sima Qian's Historical Records." Frontiers of History in China 16.1 (2021), 73-95.

Beck, Hans, and Griet Vankeerberghen, eds. Rulers and Ruled in Ancient Greece, Rome, and China. Cambridge: Cambridge University Press, 2021.

Lai, Karyn, Rick Benitez, and Hyun Jin Kim, eds. Cultivating a Good Life in Early Chinese and Ancient Greek Philosophy: Perspectives and Reverberations. London: Bloomsbury Academic, 2020.

Liu, Yan. "The Han Empire and the Hellenistic World: Prestige Gold and the Exotic Horse." Mediterranean Archaeology and Archaeometry 20.3 (2020), 175-98.

Pines, Yuri. "Limits of All-under-Heaven: Ideology and Praxis of 'Great Unity' in Early Chinese Empire." In The Limits of Universal Rule: Eurasian Empires Compared, edited by Michal Biran, Jörg Rüpke, and Yuri Pines, 79-110. Cambridge: Cambridge University Press, 2021.

Robinson, Rebecca. "Spectacular Power in the Early Han and Roman Empires." Journal of World History 29.3 (2018), 343-68. 


\section{Digital Humanities}

Books and Articles

Li, Bin, Yaxin Li, Qian Yang, Yaqi Wang, and Rui Chen. "From History Book to Digital Humanities Database: The Basic Annals of the Shiji." Journal of Chinese History 4. 2 (2020), 528-36.

Sturgeon, Donald. "Digitizing Premodern Text with the Chinese Text Project." Journal of Chinese History 4.2 (2020), 486-98.

Zhang, Yingjie, Bin Li, Xinyu Dai, Shujian Huang, and Jiajun Chen. "PQAC-WN: Constructing a Wordnet for Pre-Qin Ancient Chinese." Language Resources and Evaluation 51.2 (2017), 525-45.

\section{Economy}

\section{Books and Articles}

Brosseder, Ursula. "The Xiongnu Empire." In Handbook of Ancient Afro-Eurasian Economies: Volume 1, Contexts, edited by Sitta von Reden, 195-204. Berlin: De Gruyter Oldenbourg, 2020.

Korolkov, Maxim. "Fiscal Transformation during the Formative Period of Ancient Chinese Empire (Late Fourth to First Century BCE)." In Ancient Taxation: The Mechanics of Extraction in Comparative Perspective, edited by Jonathan Valk and Irene Soto Marín. New York: New York University Press, 2021.

Leese-Messing, Kathrin. "The Qin and Han Empires." In Handbook of Ancient Afro-Eurasian Economies: Volume 1, Contexts, edited by Sitta von Reden, 129-94. Berlin: De Gruyter Oldenbourg, 2020.

\section{Environment}

Books and Articles

Dong, Ningning, and Jing Yuan. "Rethinking Pig Domestication in China: Regional Trajectories in Central China and the Lower Yangtze Valley." Antiquity 94.376 (2020), 864-79.

Doyle, Lloyd "Allen" IV. "Toward an Ecological Civilization: Perspectives from Daoism." Journal of Daoist Studies 14.14 (2021), 221-28.

Jing, Yuan, Roderick Campbell, Lorenzo Castellano, and Chen Xianglong. "Subsistence and Persistence: Agriculture in the Central Plains of China through the Neolithic to Bronze Age Transition." Antiquity 94.376 (2020), 900-915.

Lander, Brian. "Birds and Beasts Were Many: The Ecology and Climate of the Guanzhong Basin in the Pre-Imperial Period." Early China 43 (2020), 207-45. 


\section{Reviews}

Anderson. Food and Environment in Early and Medieval China. Kuo, Chunghao Pio. East Asian Science, Technology and Society: An International Journal 13.4 (2019), 575-77.

\section{Gender}

Books and Articles

Craddock, Sarah, and John Preston. "Roles and Representations of Women in Early Chinese Philosophy: A Survey." Frontiers of Philosophy in China 15.2 (2020), 198-222.

Elias, Hajni. "Women's Role in the Production and Sale of Alcohol in Han China as Reflected in Tomb Art from Sichuan." Early China 43 (2020), 247-84.

Yang, Lei. "From Evil Women to Dissolute Rulers: Changes in Gender Representation across the Zuozhuan, Guoyu, and Shiji." Journal of the Royal Asiatic Society 30.4 (2020), 721-36.

\section{History}

Books and Articles

Bárcenas, Alejandro. El arte de la guerra completo: Sun Tzu y Sun Pin. New York: Vintage Español, 2021.

Brindley, Erica Fox. "The Concept of 'Educational Transformation' and Its Relationship to Civilizing Missions in Early China." Journal of Chinese History 5.1 (2021), 1-21.

Buljan, Ivana. "The Chunqiu Fanlu: Research on the Text and Its First Complete Western (English) Translation." Asian and African Studies 29.1 (2020), 1-25.

Cook, Constance A. "Western Zhou Rites and Mortuary Practice (Inscriptions and Texts)." In The Oxford Handbook of Early China, edited by Elizabeth Childs-Johnson, 436-50. New York: Oxford University Press, 2020.

Durrant, Stephen, Wai-yee Li, and David Schaberg. The Zuo Tradition/ Zuozhuan Reader Selections from China's Earliest Narrative History. Seattle: University of Washington Press, 2020.

Eicher, Sebastian. "Legitimität, Geschichtsschreibung und Erinnerung: Zur Verarbeitung des Todes von Kong Rong 孔融 (153-208) in den frühmittelalterlichen Überlieferungen zur späteren Han-Dynastie." In Aus geteilten Zeiten: Studien zur Nanbeichao-Periode: Geburtstagsgabe für Shing Müller, edited by Roderich Ptak, 21-36. Gossenberg: Ostasien, 2020. 
Elias, Hajni. “Stele for Magistrate Jing Yun 景雲: An Eastern Han Memorial Stele from the South-West with Reference to the Chuci 楚 辭." Bulletin of the School of Oriental and African Studies 84.1 (2021), $115-40$.

Fahr, Paul. "On the Meaning of shi 事 in Han Historiography." T'oung Pao 107.1-2 (2021), 189-96.

Galvany, Albert. "The Army, Wars, and Military Arts during the Warring States Period." In The Oxford Handbook of Early China, edited by Elizabeth Childs-Johnson, 637-56. New York: Oxford University Press, 2020.

Grebnev, Yegor. "Numerical Lists of Foundational Knowledge in Early Chinese and Early Buddhist Traditions." Asiatische Studien-Études Asiatiques 74.3 (2021), 453-84.

Hargett, James M. "Anchors of Stability: Place-Names in Early China." Sino-Platonic Papers 312 (April, 2021).

Jacoby, Marcin. "Failed Political Leadership in Ancient China: Lü Buwei and the First Emperor of Qin." In Failed Leadership, edited by Krzysztof Kasianiuk, 75-98. Berlin: Peter Lang, 2021.

Jia, Jinhua. "Constancy and Ultimate: The Space-Time Continuum in Warring States Cosmology." Journal of Daoist Studies 14. 14 (2021), 1-20.

Kern, Martin. "Beyond Nativism: Reflections on Methodology and Ethics in the Study of Early China." In At the Shores of the Sky: Asian Studies for Albert Hoffstädt, edited by Paul W. Kroll, Jonathan A. Silk, and Albert Hoffstädt, 83-98. Leiden: Brill, 2020.

Khayutina, Maria. "Reflections and Uses of the Past in Chinese Bronze Inscriptions from the Eleventh to Fifth Centuries BC: The Memory of the Conquest of Shang and the First Kings of Zhou." In Historical Consciousness and the Use of the Past in the Ancient World, edited by John Baines, Henriette van der Blom, Y. S. Chen, and Tim Rood, 157-80. Sheffield: Equinox Publishing, 2021.

Lewis, Mark Edward. "The First East Asian Empires: Qin and Han." In The Oxford World History of Empire. Vol. II: The History of Empires, edited by Peter Bang, C.A. Bayly, and Walter Scheidel, 281-239. New York: Oxford University Press, 2021.

—. Honor and Shame in Early China. Cambridge: Cambridge University Press, 2021.

Li, Wai-yee. "Cultural Identity and Cultural Difference in Zuozhuan." Journal of Chinese Literature and Culture 7.1 (2020), 7-33.

Li, Xinfeng. "Peaceful Means of Resolving Political Conflicts in the PreQin Period and Their Historical Influence." Social Sciences in China 41.2 (2020), 124-43.

Lü, Zongli. Rumor in the Early Chinese Empires. Cambridge: Cambridge University Press, 2021. 
Meyer, Andrew. "The Shi, Diplomats, and Urban Expansion during the Warring States Period." In The Oxford Handbook of Early China, edited by Elizabeth Childs-Johnson, 657-71. New York: Oxford University Press, 2020.

Meyer, Dirk. Documentation and Argument in Early China The Shàngshū 書 (Venerated Documents) and the "Sh" $\bar{u}$ "Traditions. Berlin: De Gruyter Mouton, 2021.

Milburn, Olivia. The Empress in the Pepper Chamber: Zhao Feiyan in History and Fiction. Seattle: University of Washington Press, 2021.

—. "Featherwork in Early and Medieval China." Journal of the American Oriental Society 140.3 (2020), 549-64.

Nylan, Michael. 2020. "Cross-Reading 'Kang Gao,' 'Shao Gao,' and 'Luo Gao.'” Journal of Asian History 54.1 (2020), 1-62.

Pines, Yuri. "Institutional Reforms and Reformers during the Warring States Period." In The Oxford Handbook of Early China, edited by Elizabeth Childs-Johnson, 615-22. New York: Oxford University Press, 2020.

_ . "The Warring States Period: Historical Background." In The Oxford Handbook of Early China, edited by Elizabeth Childs-Johnson, 581-94. New York: Oxford University Press, 2020.

Powers, Martin. "Theories of Dissent and Their Institutional Correlates in China." In Criticizing the Ruler in Pre-Modern Societies_Possibilities, Chances, and Methods, 299-308. Gottingen: Vandenhoeck \& Ruprecht, 2019.

Ramsden, Shaun C. R. "Indo-Europeans in the Ancient Yellow River Valley." Sino-Platonic Papers 312, 2021.

Roetz, Heiner. "On Political Dissent in Warring States China." In Criticizing the Ruler in Pre-Modern Societies-Possibilities, Chances, and Methods, 211-36. Gottingen: Vandenhoeck \& Ruprecht, 2019.

Rom, Avital Hedva. "Beat the Drums or Break Them: Bells and Drums as Communication Devices in Early Chinese Warfare." Journal of Chinese Military History 9.2 (2020), 125-67.

Sanft, Charles. "Change and Continuity at the Intersection of Received History and the Material Record during the Warring States Period." In The Oxford Handbook of Early China, edited by Elizabeth Childs-Johnson, 623-36. New York: Oxford University Press, 2020.

van Ess, Hans. “Zum ‘Ausloten Und Massieren' Im Guiguzi 鬼谷子.” In Aus Geteilten Zeiten: Studien Zur Nanbeichao-Periode: Geburtstagsgabe Für Shing Müller, edited by Roderich Ptak, 37-6o. Gossenberg: Ostasien, 2020.

Vogt, Paul. "Western Zhou Government and Society." In The Oxford Handbook of Early China, edited by Elizabeth Childs-Johnson, 401-35. New York: Oxford University Press, 2020. 
Weingarten, Oliver. "The Limits of Coercion: Rewards and Punishments in Early Chinese Military Thought." Journal Asiatique 308.1 (2020), $85-118$.

$\mathrm{Wu}$, Shu-hui. "On the Clan Relationship between Emperor Guangwu and the Gengshi Emperor and Its Historical Implications." Bochum Yearbook of East Asian Studies 42 (2019), 191-210.

Zhao, Ye. Spring and Autumn Annals of Wu and Yue: An Annotated Translation of Wu Yue Chunqiu. Translated by Jianjun He. Ithaca: Cornell University Press, 2021.

\section{Reviews}

Durrant, Li, and Schaberg. Zuo Tradition / Zuozhuan 左傳: Commentary on the "Spring and Autumn Annals". Van Auken, Newell Ann. Journal of the American Oriental Society 140.3 (2020), 737-41.

—. Vogelsang, Kai. Journal of Chinese Literature and Culture 7.2 (2020), 491-501.

Habberstad. Forming the Early Chinese Court: Rituals, Spaces, Roles. Pines, Yuri. Journal of the American Oriental Society 140.3 (2020), 720-22.

- Sanft, Charles. Harvard Journal of Asiatic Studies 80.1 (2020), 228-31.

Leung. The Politics of the Past in Early China. Falkenhausen, Lothar von. Asian Perspectives 59.2 (2020), 485-87.

Nienhauser. The Grand Scribe's Records. Volume XI, The Memoirs of Han China, Part IV. Hardy, Grant. China Review International 25.3 (2018), 287-89.

Pirazzoli-t'Serstevens and Bujard. Les Dynasties Qin et Han. Histoire Générale de La Chine (221 Av. J.-C.-220 Apr. J.-C.). Staack, Thies. Arts Asiatiques 75 (2020), 190-91.

Poo. Daily Life in Ancient China. Loewe, Michael. Journal of the American Oriental Society 140.2 (2020), 495-99.

Sanft. Literate Community in Early Imperial China: The Northwestern Frontier in Han Times. Wu, Sujane. China Review International 26.1 (2019), 105-9.

Sebastian. Das Hou Han Ji des Yuan Hong: Zur Historiographie der späteren Han-Dynastie. Fölster, Max Jakob. Bulletin de l'École Française d'Extrême-Orient 105 (2019), 395-400.

Sterckx, Siebert, Schäfer, eds. Animals through Chinese History: Earliest Times to 1911. Cao, Deborah. Isis 111.1 (2020), 143-44.

—. Doran, Rebecca. Journal of the American Oriental Society 140.4 (2020), 979-81.

- Kuo, Chunghao Pio. East Asian Science, Technology and Society: An International Journal 14.4 (2020), 681-83.

—. Rothfels, Nigel. 2020. The American Historical Review 125.5 (2020), 1836-38. 
Zhao. In Pursuit of the Great Peace: Han Dynasty Classicism and the Making of Early Medieval Literati Culture. Espesset, Grégoire. Journal of Chinese Studies 72 (2021), 181-218.

\section{Literature}

Books and Articles

Allen, Joseph Roe. The Chinese Lyric Sequence: Poems, Paintings, Anthologies. Amherst: Cambria Press, 2020.

Qin, Amelia Ying. "Anecdotes for Reminders: Performed Oral Culture in the 'Guji Liezhuan.'" Chinese Literature: Essays, Articles, Reviews 42 (2020), 1-32.

\section{Medicine}

Books and articles

Raphals, Lisa. "Body, Mind, and Spirit in Early Chinese Medicine." T'oung Pao 106.5-6 (2020), 525-51.

\section{Paleography and Excavated Texts}

Books and Articles

Back, Youngsun. “Revealing Contingency through Shun's 舜 Ascension to the Throne." Early China 43 (2020), 61-92.

Cao, Jianguo. "Misplacement, Re-Edition or Funerary Object: On the Textual Features of the Anhui Shijing Manuscript and Its Value." Bamboo and Silk 4.1 (2021), 94-127.

Chen, Hung-sen. "Some Minor Insights from Reading the Anhui University Warring States Bamboo Slips of the Classic of Poetry." Bamboo and Silk 4.1 (2021), 172-88.

Chen, Liang. Begräbnistexte Im Sozialen Wandel Der Han-Zeit: Eine Typologische Untersuchung Der Jenseitsvorstellungen. Heidelberg; Berlin: CrossAsia-eBooks, 20201.

Fa, Li. "Primordial Unfolding: 120 Years of Periodization and Classification of the Oracle Bone Inscriptions." Chinese Studies in History 53.4 (2020), 311-30.

Fech, Andrej. "The Relationship between the Zhou Xun 周訓 and Lüshi Chunqiu 呂氏春秋 in the Context of the Late Warring States Period." Bulletin of the Jao Tsung-I Academy of Sinology 7 (2020), 153-82.

Grundmann, Joern Peter. "The Question of Literariness in the Composition of Western Zhou Bronze Bell Inscriptions." Bulletin of the Jao Tsung-I Academy of Sinology 7 (2020), 91-114. 
Herzog, Alexander. "Rechtsvorschriften Und Deren Ausführung in Der Qin-Dynastie Am Beispiel Der Liye-Holztäfelchen." Bochum Yearbook of East Asian Studies 42 (2019), 5-36.

Jiang, Wen. "A Re-Examination of the Controversy over the Oral and Written Nature of the Classic of Poetry's Early Transmission, Based on the Anhui University Manuscript." Bamboo and Silk 4.1 (2021), $128-48$.

Liu, Gang. "A Reconstruction of the Text of the Poem 'You Bi' of the Liturgies of Lu Section of the Classic of Poetry." Bamboo and Silk 4.1 (2021), 189-99.

Ma, Tsang Wing. "Between the State and Their Superiors: The Anxiety of Low-Ranked Scribes in the Qin and Han Bureaucracies." Asia Major (3rd ser.) 33.2 (2020), 25-59.

Puett, Michael. "Impagination, Reading, and Interpretation in Early Chinese Texts." In Impagination - Layout and Materiality of Writing and Publication: Interdisciplinary Approaches from East and West, edited by Ku-ming Kevin Chang, Anthony Grafton, and Glenn W. Most, 93109. Berlin: De Gruyter, 2021.

Saussy, Haun. "Reading from, Reading into: The Challenge of the Bamboo Odes." Bamboo and Silk 4.1 (2021), 200-213.

Schwartz, Adam. "How to Read an Oracle Bone from Huayuanzhuang East Pit H3." Bulletin of the Jao Tsung-I Academy of Sinology 7 (2020), 39-40.

Shaughnessy, Edward L. "A Possible Lost Classic: The *She Ming, or *Command to She." T'oung Pao 106.3-4 (2020), 266-308.

Staack, Thies. "From Copies of Individual Decrees to Compilations of Written Law: On Paratextual Framing in Early Chinese Legal Manuscripts." In Copying Manuscripts: Textual and Material Craftsmanship, edited by Antonella Brita, Giovanni Ciotti, Florinda De Simini, and Amneris Roselli, 183-240. Naples: Università degli Studi di Napoli "L'Orientale," Dipartimento Asia Africa e Mediterraneo, 2020.

Sun, Yabing. "Manifold and Splendid: 120 Years of Research on the Oracle Bone Inscriptions and Shang History." Chinese Studies in History 53.4 (2020), 351-68.

Wang, Q. Edward, and Guolong Lai. "The Scholarship on Oracle Bones and Oracle Bone Inscriptions: Retrospect and Prospect-Introduction." Chinese Studies in History 53.4 (2020), 307-10.

Waring, Luke. "Introducing the *Wu Ze You Xing Tu Manuscript from Mawangdui." Early China 43 (2020), 123-60.

Yen, Shih-hsuan. "A Tentative Discussion of Some Phenomena Concerning Early Texts of the Shi Jing." Bamboo and Silk 4.1 (2021), 45-93.

Yuasa, Kunihiro. "On Stanzaic Inversion in the Qin Feng 秦風 Ode 'Sitie' 駟驖 (Iron-Black Horses) in the Anhui University Bamboo 
Manuscript of the Shi Jing 詩經 (Classic of Odes)." Bamboo and Silk 4.1 (2021), 149-71.

Yubin, Jiang. "Joining Jades and Linking Pearls: 120 Years of Rejoining Fragmented Oracle Bone Inscriptions." Chinese Studies in History 53.4 (2020), 331-50.

\section{Reviews}

Allan. Buried Ideas: Legends of Abdication and Ideal Government in Early Chinese Bamboo-Slip Manuscripts. Lebovitz, David J. Journal of Chinese Humanities 6.1 (2020), 115-21.

Barbieri-Low and Yates. Law, State and Society in Early Imperial China: A Study with Critical Edition and Translation of the Legal Texts from Zhangjiashan Tomb No. 24. Bourgon, Jérôme. T'oung Pao 106.3-4 (2020), 459-65.

Caldwell. Writing Chinese Laws: The Form and Function of Legal Statutes Found in the Qin Shuihudi Corpus. Staack, Thies. Journal of the American Oriental Society 140.3 (2020), 718-19.

Chan, ed. Reading Through Recovered Ancient Chinese Manuscripts. Sellmann, James. Philosophy East and West 70.4 (2020), 1-4.

Harper and Kalinowski, eds. Books of Fate and Popular Culture in Early China: The Daybook Manuscripts of the Warring States, Qin, and Han. Cheng, Shaoxuan. Bamboo and Silk 4.I (2021), 215-31.

Pines. Zhou History Unearthed: The Bamboo Manuscript Xinian and Early Chinese Historiography. Shaughnessy, Edward L. T'oung Pao 107.1-2 (2021), 205-11.

van Els. The Wenzi: Creativity and Intertextuality in Early Chinese Philosophy. Meyer, Andrew. Journal of the American Oriental Society 140.3 (2020), 730-33.

\section{Philology and Linguistics}

Books and articles

Hwang, Ming-chorng. "Genes, Language Families, and Writing Systems: Rethinking the Origin of Chinese Writing." In Dialogue of Four Pristine Writing Systems, edited by Kuang Yu Chen, Dietrich Tschanz, and Ching-I Tu, 125-44. New Brunswick: Confucius Institute of Rutgers University, 2019.

Pellin, Tommaso. "Some Conceptual Metaphors for $J u$ 句 in Early Traditional Chinese Linguistics." Bochum Yearbook of East Asian Studies 42 (2019), 115-44.

Schuessler, Axel. "Questions about Baxter \& Sagart's Old Chinese." Bulletin of the Jao Tsung-I Academy of Sinology 6 (2019), 83-103. 


\section{Religion and Philosophy}

Books and Articles

Ames, Roger T. Confucian Role Ethics: A Vocabulary. Albany: State University of New York Press, 2020.

—. Human Becomings: Theorizing Persons for Confucian Role Ethics. Albany: State University of New York Press, 2021.

Andrus, Gabriel. "Ancient Chinese Proofs for the Existence of Gods: The Case of Mohism." Asian Philosophy 31.2 (2021), 105-20.

Bender, Jacob. "The 'Non-Naturalistic Fallacy' in Lao-Zhuang Daoism." Philosophy East and West 71.2 (2021), 265-86.

Bergeton, Uffe. "Found (and Lost?) in Translation: Culture in The Analects." Harvard Journal of Asiatic Studies 79.1-2 (2019), 49-95.

Brindley, Erica F. "Capturing the World in Words: Later Mohist Hermeneutic Theories on Language and Disputation." Early China 43 (2020), 93-121.

Brunozzi, Philippe. "Moral Theorizing and the Source of Normativity in Classical Chinese Philosophy: An Outline." Dao: A Journal of Comparative Philosophy 19.3 (2020), 335-51.

Brusadelli, Federico. "The Vital Centre: Understanding the Concept of Yao 要 in the Han Feizi 韓非子." Asiatische Studien-Études Asiatiques $74 \cdot 3$ (2021), 635-54.

Cai, Liang. "How Strong Is Your Love for Your Parents? Childlike Mindset and the Confucian View of Filial Piety." Bulletin of the Jao Tsung-I Academy of Sinology 7 (2020), 225-54.

Chang, Yao-Cheng. "An Exceptional Portrait of Yang Zhu and Mozi Beyond the Mencian Track." Asian Studies 9.1 (2021), 203-24.

Cook, Scott. "Confucius and the Analects Revisited, Revisited." Chinese Literature: Essays, Articles, Reviews 41 (2019), 125-64.

Crone, Thomas. Between Disaster, Punishment, and Blame The Semantic Field of Guilt in Early Chinese Texts. Wiesbaden: Otto Harrassowitz, 2020.

Curzer, Howard. "Stingy King Meets Savvy Sage: Rethinking the Dialog between King Xuan of Qi and Mengzi." Dao 19.3 (2020), 371-89.

D'Ambrosio, Paul J. "Reading the Zhuangzi Playfully: Stepping Back from 'Ancient Chinese Wisdom.'" Asian Philosophy 30.3 (2020), 214-29.

Defoort, Carine. "Mohism and the Evolving Notion of Jian Ai." In The Oxford Handbook of Early China, edited by Elizabeth Childs-Johnson, 698-710. New York: Oxford University Press, 2020.

Ding, Sixin. "The Debate Surrounding 'Dismiss the Hundred Schools of Thought and Revere Only the Confucian Arts' and a Refutation of the Theory of the Autocracy of Han Dynasty Confucian Thought." Contemporary Chinese Thought 51.2 (2020), 96-122. 
Fraser, Chris. "Identifying Upward: Political Epistemology in an Early Chinese Political Theory." In The Routledge Handbook of Political Epistemology, edited by Michael Hannon and Jeron de Ridder, 24-34. New York: Routledge, 2021.

—. "Realism about Kinds in Later Mohism." Dao 20.1 (2021), 93-114.

Fraser, Chris. "Representation in Early Chinese Philosophy of Language." Philosophy East and West 71.1 (2021), 57-78.

_. "Understanding 'Confucianism Becoming the Dominant School of Thought.'" Contemporary Chinese Thought 51.2 (2020), 123-39.

Goldin, Paul Rakita. The Art of Chinese Philosophy: Eight Classical Texts and How to Read Them. Princeton: Princeton University Press, 2020.

Graziani, Romain. Fiction and Philosophy in the Zhuangzi: An Introduction to Early Chinese Taoist Thought. London: Bloomsbury Academic, 2021.

Grebnev, Yegor. "Aural-Mnemonic Architectonics of Ancient Chinese Philosophical Texts." Monumenta Serica 68.2 (2020), 289-314.

Hamm, Matthew James. "A Dream of the Self: Identity in the 'Inner Chapters' of the Zhuangzi." Early China 43 (2020), $29-60$.

$\mathrm{He}$, Fan. "How to Unite a Society with Divisions and Differences." Monumenta Serica 68.2 (2020), 315-37.

He, Jianjun. "Anxiety over the Filial Body: Discussions on Xiao in Early Confucian Texts." Journal of the American Oriental Society 140.2 (2020), 301-15.

$\mathrm{Hu}$, Xiangnong. "The Relativity of Ren (Humaneness) Re-Examining 2A6 and 6A6 of the Mengzi from the Perspective of Self-Introspection in Experience." Asian Studies 9.1 (2021), 181-201.

Indraccolo, Lisa. "Political Rhetoric in the Hán Fêizì 韓非子: A Structural Analysis of Chapter 12 'Shuìnán' 說難." Asiatische Studien一Études Asiatiques 74.3 (2021), 655-86.

Kan, Huai-chen. "The Establishment of the Suburban Sacrifice Rituals During the Western Han." Contemporary Chinese Thought 51.2 (2020), 140-73.

Kern, Martin. "Beyond Nativism: Reflections on Methodology and Ethics in the Study of Early China." In "At the Shores of the Sky": Asian Studies for Albert Hoffstädt, edited by Paul W. Kroll, Jonathan A Silk, and Albert Hoffstädt, 83-98. Leiden: Brill, 2020.

Kim, Doil. “Qian 謙 in Early Chinese Thought." Early China 43 (2020), 1-27.

Leung, Vincent S. "Mozi." In The Oxford Handbook of Early China, edited by Elizabeth Childs-Johnson, 685-97. New York: Oxford University Press, 2020.

L'Haridon, Béatrice. "L'accord et sa dimension rituelle dans le Confucianisme ancien." Antiquorum Philosophia 13 (2019), 73-90. 
Liang, Tao. "Beyond Respecting Mencius and Criticizing Xunzi: A Return to Equal Status for the Two Sages." Journal of Chinese Humanities 6.1 (2020), 43-63.

Liu, Gusheng, and Haijie Li. "The Thought of Yang Zhu in the History of Laozi's Thought: Along with a Discussion of the Authenticity of the Liezi." Contemporary Chinese Thought 50.3-4 (2019), 75-91.

Lu, Xiufen. "Xunzi: Moral Education and Transformation." Asian Philosophy 30.4 (2020), 340-50.

Lü, Zongli. Rumor in the Early Chinese Empires. Cambridge: Cambridge University Press, 2021.

Lucas, Thierry. "The Logical Style of Confucius' Analects." Frontiers of Philosophy in China 15.2 (2020), 167-97.

Ma, Lin, and Jaap van Brakel. Beyond the Troubled Water of Shifei: From Disputation to Walking-Two-Roads in the "Zhuangzi". Albany: State University of New York Press, 2019.

Ma, Lin, and Jaap van Brakel. "Revisiting the Exchange between Zhuangzi and Huizi on Qing." Dao 20.1 (2021), 133-48.

$\mathrm{Ng}$, Ashton. "Is the Laozi a Text on Statecraft?" Bochum Yearbook of East Asian Studies 42 (2019), 84-114.

Nylan, Michael. "The Documents Classic as Guide to Political Philosophy in the Early Empires." Journal of Chinese Philosophy 48.1 (2021), 40-55.

Olberding, Amy. The Wrong of Rudeness: Learning Modern Civility from Ancient Chinese Philosophy. New York: Oxford University Press, 2019.

O'Neil, Brandon James. “The Way of Family Devotion: The Book of Filial Piety." Journal of Daoist Studies 14.14 (2021), 171-83.

Pang-White, Ann A. "Virtues and the Book of Rites." Journal of Chinese Philosophy 48.1 (2021), 56-70.

Parreño Piñol, Manuel. "Goodness Is Like Water: Laozi's Vision of Fundamental Nature, Life, and Light." Journal of Daoist Studies 14.14 (2021), 153-70.

Pines, Yuri. "Names and Titles in Eastern Zhou Texts." T'oung Pao 106.56 (2020), 714-20.

— - "Worth vs. Power: Han Fei's 'Objection to Positional Power' Revisited." Asiatische Studien-Études Asiatiques 74.3 (2020), 687-710.

Puett, Michael. "Formations of Knowledge in Chinese Late Antiquity." In Wissensoikonomien: Ordnung Und Transgression Vormoderner Kulturen, edited by Nikolas Pissis, Nora Schmidt, and Gyburg Radke-Uhlmann, 123-33. Wiesbaden: Harrassowitz, 2021.

Raphals, Lisa. "Virtue, Body, Mind and Spirit in the Shijing: New Perspectives on Pre-Warring States Conceptions of Personhood and Virtue." Journal of Chinese Philosophy 48.1 (2021), 28-39. 
Roberts, Moss. The Analects: Conclusions and Conversations of Confucius.

Oakland: University of California Press, 2020.

—. "Confucius, Mencius, and Their Daoist-Legalist Critics." In The Oxford Handbook of Early China, edited by Elizabeth Childs-Johnson, 672-84. New York: Oxford University Press, 2020.

Rosker, Jana. "Ban Zhao and the Question of Female Philosophy in China." Asian and African Studies 29.2 (2020), 239-60.

Schneider, Henrique. "Tricking or Benefitting the People? Guanzi on Objective Government and Subjective Preferences." Frontiers of Philosophy in China 14.3 (2019), 363-83.

Shaughnessy, Edward L. "A First Reading of the Anhui University Bamboo-Slip Shi Jing." Bamboo and Silk 4.1 (2021), 1-44.

Shun, Kwong-loi. "Dimensions of Humility in Early Confucian Thought." Journal of Chinese Philosophy 48.1 (2021), 13-27.

Sikri, Rohan. "The Dialectics of Yangsheng: Healing by Argument in the Zhuangzi." Philosophy East and West 71.2 (2021), 431-50.

Song, Yunwoo. "Differing Views on Heaven's Role in Accounts of Undeserved Hardship in Early China." Philosophy East and West 70.3 (2020), 801-18.

—. "Wang Chong's Fatalism." Early China 43 (2020), 285-310.

Suter, Rafael, Lisa Indraccolo, and Wolfgang Behr, eds. The Gongsun Longzi and Other Neglected Texts: Aligning Philosophical and Philological Perspectives. Berlin: De Gruyter, 2020.

Williams, Nicholas Morrow. "Shamans, Souls, and Soma: Comparative Religion and Early China." Journal of Chinese Religions 48.2 (2020), 147-73. Wu, Zhu. "The Timely Manner of Confucius and the Personality Symbolism of Birds and Beasts: A New Interpretation of Analects 10.27." Journal of Chinese Studies 71 (2020), 1-19.

Yang, Soon-ja. "Yi as 'Meaning-Bestowing' in the Xunzi." Dao 20.1 (2021), 115-31.

Yao, Xinzhong. "De and Virtue in Early Confucian Texts: Introduction." Journal of Chinese Philosophy 48.1 (2021), 5-12.

\section{Reviews}

Bai. Against Political Equality: The Confucian Case. Li, Zhuoyao. Philosophy East and West 71.1 (2021), 1-3.

Birrell. Shamanism in Early China. Michael, Thomas. Monumenta Serica 68. 2 (2020), 563-67.

Cook. Ancestors, Kings, and the Dao. Tavor, Ori. Journal of Chinese Religions 48.2 (2020), 285-87.

Du. Shang Shu Zhushu Huijiao 尚書注疏彙校 [Collected Collation on Annotations of Shang Shu] and Shang Shu Zhushu Jiaoyi 尚書注疏校議 
[Notes on the Collation Work of Annotations of Shang Shu]. Shaughnessy, Edward L. Journal of Chinese Humanities 5.2 (2020), 245-48.

Fraser. The Essential Mozi: Ethical, Political, and Dialectical Writings. Wu, Yun. Dao 19. 4 (2020), 671-73.

Hunter and Kern, eds. Confucius and the Analects Revisited: New Perspectives on Composition, Dating, and Authorship. Dunlap, Rika. Frontiers of Philosophy in China 15.4 (2020), 682-86.

Liu. Gongsun Long Zi: Chongshi yu Chongyi 《公孫龍子: 重釋與重譯》. Huang, Qiao. Journal of Chinese Philosophy 47.3-4 (2020), 328-32.

Ma and Van Brakel. Beyond the Troubled Water of Shifei: From Disputation to Walking-Two-Roads in the "Zhuangzi". Saunders, Frank P. Jr. Philosophy East and West 70.3 (2020), 1-4.

Nylan. The Chinese Pleasure Book. Lambert, Andrew. Philosophy East and West 70.4 (2020), 1-5.

—. Noel, Thomas Donnelly. Chinese Literature: Essays, Articles, Reviews 42 (2020), 178-81.

Olberding. The Wrong of Rudeness: Learning Modern Civility from Ancient Chinese Philosophy. Kádár, Dániel Z. China Review International 25.2 (2018), 153-56.

Slingerland. Mind and Body in Early China: Beyond Orientalism and the Myth of Holism. Barrett, T. H. Bulletin of the School of Oriental and African Studies 83.3 (2020), 551-54.

—. Seok, Bongrae. Philosophy East and West 70.3 (2020), 1-6.

Ziporyn. Zhuangzi: The Complete Writings. Chen, Guo. Philosophy East and West 70.4 (2020), 1-5.

—. Moeller, Hans-Georg. Journal of Chinese Religions 48.2 (2020), 311-14.

\section{Science and Technology}

Books and Articles

Bréard, Andrea, and Constance A. Cook. "Cracking Bones and Numbers: Solving the Enigma of Numerical Sequences on Ancient Chinese Artifacts." Archive for History of Exact Sciences 74.4 (2020), 313-43.

Chemla, Karine. "On the Diagrammaticity of Ancient Texts and Its Importance for the History of Science: Based on the Example of the Early Chinese Mathematical Text The Gnomon of the Zhou." East Asian Science, Technology and Society: An International Journal 14.2 (2020), 279-308.

Kory, Stephan N. "Omen Watching, Mantic Observation, Aeromancy, and Learning to 'See': The Rise and Messy Multiplicity of Zhanhou 
占候 in Late Han and Medieval China." East Asian Science, Technology, and Medicine 50.1 (2019), 67-131.

Reviews

Golas. Picturing Technology in China. From Earliest Times to the Nineteenth Century. Spicq, Delphine. East Asian Science, Technology, and Medicine 50 (2019), 163-67.

Jun. Ancient Chinese Encyclopedia of Technology: Translation and Annotation of the Kaogong Ji (The Artificer's Record). Lien, Y. Edmund. Journal of the American Oriental Society 140.3 (2020), 726-30.

\section{Miscellaneous}

Will, Pierre-Étienne. “Jacques Gernet (1921-2018)." T'oung Pao 106.5-6 (2020), 487-524. 